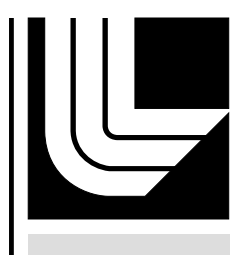

LAW RENCE LIVERMORE N A TIO N A L LABORATORY

\section{CORROSION STUDY OF AMORPHOUS METAL RIBBONS}

T. Lian, S. D. Day, J. C. Farmer

August 2, 2006 
This document was prepared as an account of work sponsored by an agency of the United States Government. Neither the United States Government nor the University of California nor any of their employees, makes any warranty, express or implied, or assumes any legal liability or responsibility for the accuracy, completeness, or usefulness of any information, apparatus, product, or process disclosed, or represents that its use would not infringe privately owned rights. Reference herein to any specific commercial product, process, or service by trade name, trademark, manufacturer, or otherwise, does not necessarily constitute or imply its endorsement, recommendation, or favoring by the United States Government or the University of California. The views and opinions of authors expressed herein do not necessarily state or reflect those of the United States Government or the University of California, and shall not be used for advertising or product endorsement purposes.

This work was performed under the auspices of the U.S. Department of Energy by University of California, Lawrence Livermore National Laboratory under Contract W-7405-Eng-48. 


\title{
CORROSION STUDY OF AMORPHOUS METAL RIBBONS
}

\author{
T. Lian, S. D. Day, \& J. C. Farmer \\ Lawrence Livermore National Laboratory
}

\section{INTRODUCTION}

Corrosion costs the Department of Defense billions of dollars every year, with an immense quantity of material in various structures undergoing corrosion. For example, in addition to fluid and seawater piping, ballast tanks, and propulsions systems, approximately 345 million square feet of structure aboard naval ships and crafts require costly corrosion control measures. The use of advanced corrosion-resistant materials to prevent the continuous degradation of this massive surface area would be extremely beneficial. The potential advantages of amorphous metals have been recognized for some time [Latanison 1985]. Iron-based corrosion-resistant, amorphous-metal coatings under development may prove important for maritime applications [Farmer et al. 2005].

Such materials could also be used to coat the entire outer surface of containers for the transportation and longterm storage of spent nuclear fuel, or to protect welds and heat affected zones, thereby preventing exposure to environments that might cause stress corrosion cracking [Farmer et al. 1991, 2000a, 2000b]. In the future, it may be possible to substitute such high-performance iron-based materials for more-expensive nickel-based alloys, thereby enabling cost savings in a wide variety of industrial applications. It should be noted that thermal-spray ceramic coatings have also been investigated for such applications [Haslam et al. 2005].

This report focuses on the corrosion resistance of iron-based melt-spun amorphous metal ribbons. Melt-Spun ribbon is made by rapid solidification ---- a stream of molten metal is dropped onto a spinning copper wheel, a process that enables the manufacture of amorphous metals which are unable to be manufactured by conventional cold or hot rolling techniques. The study of melt-spun ribbon allows quick evaluation of amorphous metals corrosion resistance. The melt-spun ribbons included in this study are DAR40, SAM7, and SAM8, SAM1X series, and SAM2X series. The SAM1X series ribbons have Ni additions in increments of 1,3,5, and 7 atom percent, to DAR40. For example, $1 \mathrm{X} 7$ means a composition of 7 -atom $\% \mathrm{Ni}$ added to 93 -atom\% of DAR 40 . Similarly, The SAM1X series ribbons have Mo additions in increments of 1,3,5, and 7 atom percent, to DAR40. For example, $2 \mathrm{X} 3$ means a composition of 3-atom\% Mo added to 97 -atom\% of DAR40. SAM7 ribbon is a Fe-Cr-Mo-Y-C-B metal glass, commonly called Alloy1651. SAM8 is SAM7 with an additional 3-atom\% W. The nominal compositions of DAR40 and SAM7 are listed in Table 1. SAM7 ribbon is extremely brittle and hard to manufactured by melt-spinning, only limited number of SAM7 ribbons were tested.

\section{EXPERIMENTS}

Corrosion tests were to perform cyclic polarization measurements on melt-spun ribbons in various aqueous solutions include acidic (pH 2) $3.5 \mathrm{~m} \mathrm{NaCl}$, basic ( $\mathrm{pH}$ 12) $3.5 \mathrm{NaCl}, 5 \mathrm{M} \mathrm{CaCl}_{2}$, and seawater from Half Moon Bay, California. Each test ribbon was partially encapsulated in epoxy to allow a $2 \mathrm{~cm}$ long ribbon exposed for corrosion tests. The epoxy protects the electrical contact from exposure to the test solution.

A temperature-controlled, borosilicate glass (Pyrex) cell was used for the electrochemical tests. This five-port cell had a working electrode (the test specimen), a reference electrode, and a counter electrode. A standard silver silver-chloride electrode, filled with near-saturation potassium chloride solution, was used as the reference, and communicated with the test solution via a Luggin probe placed in close proximity to the working electrode to minimize Ohmic losses. Numerical corrections for the reference electrode junction potential have been estimated, and have been found to be insignificant (Farmer et al. 2000a). The Luggin probe is equipped with a water-cooled jacket to keep the reference electrode at ambient temperature, thereby maintaining an accurate potential 
measurement. A water-cooled condenser was inserted into the vessel to prevent the loss of volatile species from the electrolyte. The solution was deaerated using a bubbled nitrogen gas purge through a fifth port.

Each electrochemical test includes a potentiodynamic polarization measurement after a 24-hour immersion in test solutions. A scan rate of $0.167 \mathrm{mV} / \mathrm{s}$ ( or $600 \mathrm{mV} / \mathrm{hr}$ ) was used in the potentiodynamic scans. All tests were conducted at either $90^{\circ} \mathrm{C}$, or $105^{\circ} \mathrm{C}$ for the tests in $\mathrm{CaCl}_{2}$ solutions.

\section{RESULTS AND CONCLUSIONS}

Figure 1 shows the anodic polarization curves of SAM1X ribbons in acidic $3.5 \mathrm{~m} \mathrm{NaCl}$ solutions at $90^{\circ} \mathrm{C}$. It appears that added $\mathrm{Ni}$ does not improve corrosion resistance. Figure 2 shows the similar corrosion behavior demonstrated by SAM2X ribbons in acidified $\mathrm{NaCl}$ solution, the added Mo did not enhance corrosion resistance. These findings may indicate that SAM1X and SAM2X ribbons are not resistant to low $\mathrm{pH}$ chloride-containing environments. Future tests will be conducted in solutions with higher $\mathrm{pH}$ values to investigate the effects of $\mathrm{Ni}$ and Mo on the corrosion resistance of Fe-based amorphous metals in neutral and basic environments.

Figure 3 shows the anodic polarization curves of DAR40 ribbons in chloride solutions with $\mathrm{pH}$ ranging from 2 to 12. By analyzing the polarization behavior, it is noted that DAR40 had better corrosion resistance in the solutions with neutral or higher $\mathrm{pH}$. DAR40 showed excellent corrosion resistance in $5 \mathrm{M} \mathrm{CaCl}_{2}$ solution at $105^{\circ} \mathrm{C}$, as well as in $90^{\circ} \mathrm{C}$ seawater. It is reported that $5 \mathrm{M} \mathrm{CaCl}_{2}$ severely attacks Alloy 22, a high-grade Ni-based alloy that is currently considered as container material for the Yucca Mountain high-level nuclear waste repository. Figure 4 shows the anodic polarization curves of SAM2X5 ribbons in chloride solutions with $\mathrm{pH}$ ranging from 2 to 12 . The overall corrosion resistance of SAM2X5 is similar to that of DAR40.

Figure 5 displays the anodic polarization curves of SAM8 ribbons in chloride solutions with $\mathrm{pH}$ ranging from 2 to 12. Although SAM8 ribbon displayed less than desirable corrosion resistance in acidic $\mathrm{NaCl}$ solution, it performed relatively better than DAR40 and SAM2X5, (see Figures 3, 4 \& 5). This may be attributed to a higher Mo content (approximately 15-atom\%) in SAM8. Figure 6 shows that SAM7 (SAM1651) and SAM8 behaved identically in seawater at $90^{\circ} \mathrm{C}$. It is reasonable to speculate that SAM7 and SAM8 have similar corrosion resistance in the environments listed in this report.

Figure 7 exhibits strong effects of thermal treatment on the corrosion resistance of SAM7 ribbons. The polarization curves, obtained in seawater at $90^{\circ} \mathrm{C}$, of SAM7 ribbons subjected to various heat treatment conditions implied that SAM7 devitrification likely occurred at temperature as low as $600^{\circ} \mathrm{C}$. The corrosion resistance of SAM7 ribbons further decreased with higher heat treatment temperature, due to higher degrees of devitrification at $800^{\circ} \mathrm{C}$ and $1000^{\circ} \mathrm{C}$. This fully demonstrates that amorphous state is the key to a material having superior corrosion resistance.

The corrosion study results included in this report has not been corroborated by materials characterization techniques such as X-ray diffraction (XRD) for crystallinity, scanning electron microscopy (SEM) for surface morphology, energy dispersive spectroscopy (EDS) and inductively coupled plasma mass spectrometer (ICPMS) for chemical composition. These results will be reported elsewhere. 


\section{ACKNOWLEDGMENTS}

Work was sponsored by the United States Department of Energy (DOE) Office of Science and Technology International (OSTI). This work was done under the auspices of the U.S. DOE by Lawrence Livermore National Laboratory (LLNL) under Contract No. W-7405-Eng-48.

The HPCRM Team expresses their gratitude to sponsors for financial support, and supportive colleagues for making this work possible. Special thanks to Jeffrey Walker (DOE OSTI) for sharing his insights and knowledge in fields of engineering and materials science, and for his innovative solutions to many of the technical problems that have been addressed. Professor Joseph Payer of Case Western Reserve University is also gratefully acknowledged. His guidance has helped the HPCRM Team reach its current level of scientific and technical success.

Special thanks to The NanoSteel Company for fabricating the melt-spun ribbons used in this investigation. These materials were prepared under contract for Lawrence Livermore National Laboratory.

\section{REFERENCE}

J. C. Farmer et al., Nuclear Engineering Design, Vol. 129, pp. 57-88 (1991).

J. C. Farmer et al., Proc. 2000 ASME Pressure Vessel and Piping (PVP) Conference, Seattle, Washington, July 2327, 2000, Transportation, Storage, and Disposal of Radioactive Materials, American Society of Mechanical Engineers, New York, NY, PVP Vol. 408, pp. 53-70 (2000a).

J. C. Farmer et al., Proc. 2000 ASME Pressure Vessel and Piping (PVP) Conference, Seattle, Washington, July 2327, 2000, Transportation, Storage, and Disposal of Radioactive Materials, American Society of Mechanical Engineers, New York NY, PVP Vol. 408, pp. 71-81 (2000b).

J. C. Farmer et al., Proc. 2005 ASME Pressure Vessel and Piping (PVP) Conference, Denver, Colorado, July 17-21, 2005, American Society of Mechanical Engineers, PVP2005-71664, New York, NY, 7 p. (2005a).

J. C. Farmer et al., DARPA-DOE High-Performance Corrosion-Resistant Materials Principal Investigator's Meeting, UCRL-PRES-214672, Turtle Bay Resort, Oahu, Hawaii, January 10-13, 2005, Lawrence Livermore National Laboratory, Livermore, California, 407 pages (2005b).

J. J. Haslam, J. C. Farmer, R. W. Hopper, K. R. Wilfinger, Ceramic Coatings for Corrosion Resistant Nuclear Waste Container Evaluated in Simulated Ground Water at 90C, UCRL-JRNL-206107; Metallurgical and Materials Transactions A, Volume 36A, May 2005, p. 1085-1095 (2004).

R. M. Latanison, Workshop on Amorphous Metals and Semiconductors, EPRI, May 12-18 (1985).

Table 1. Nominal Composition of DAR40 and SAM7 ribbons

\begin{tabular}{|c|c|c|c|c|c|c|c|c|c|}
\hline & Fe (\%) & Cr (\%) & Mo (\%) & C (\%) & Y (\%) & B (\%) & W (\%) & Mn (\%) & Si (\%) \\
\hline DAR40 & 52.3 & 19.0 & 2.5 & 4.0 & & 16.0 & 1.7 & 2 & 2.5 \\
\hline SAM7 & 48.0 & 15.0 & 14.0 & 15.0 & 2.0 & 6.0 & & & \\
\hline
\end{tabular}




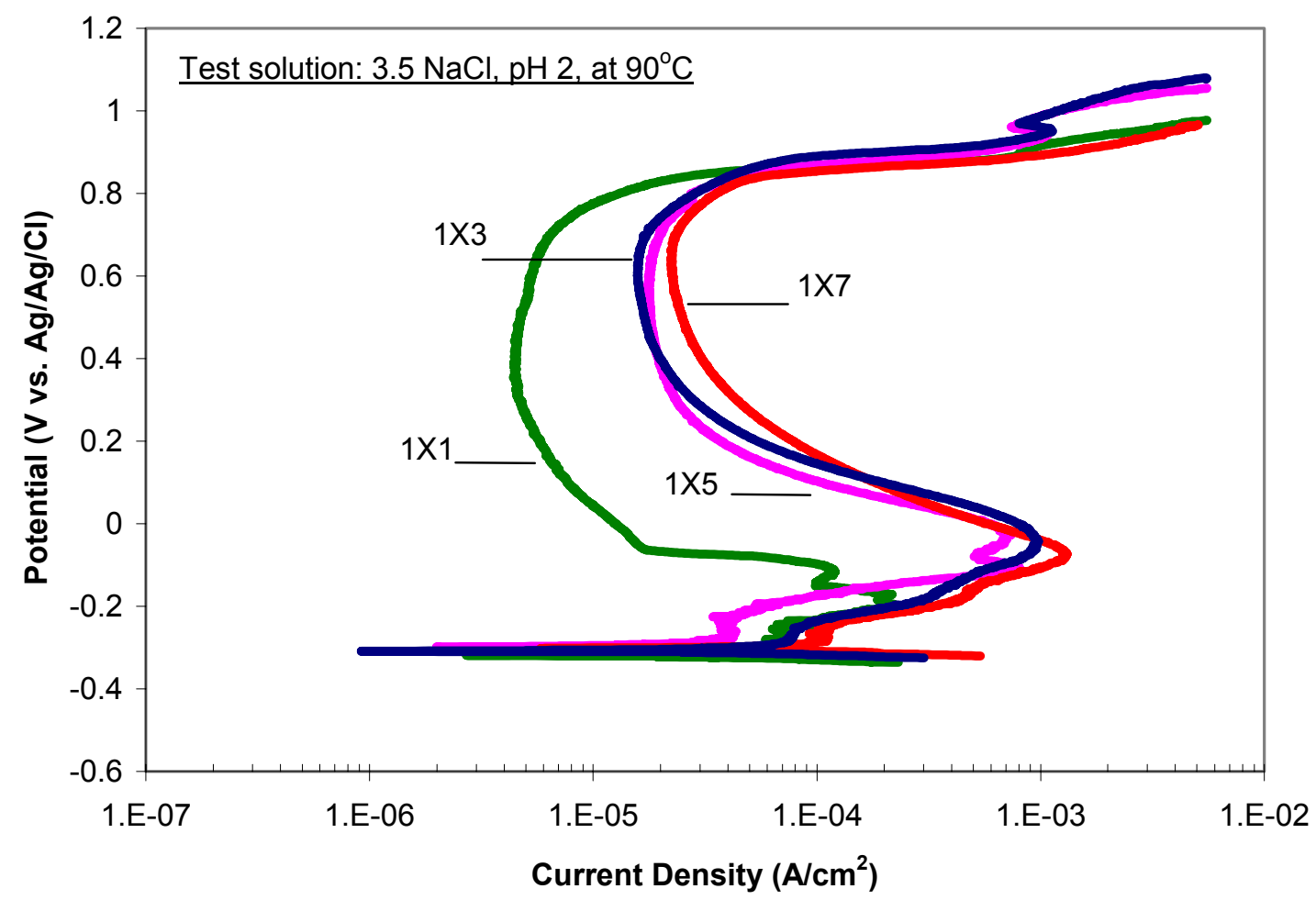

Figure 1. The corrosion resistance of SAM1X series ribbons in acidic $(\mathrm{pH} 2)$ chloride solutions. SAM1X7 has the highest Ni content, while SAM1X1 has the lowest Ni content.

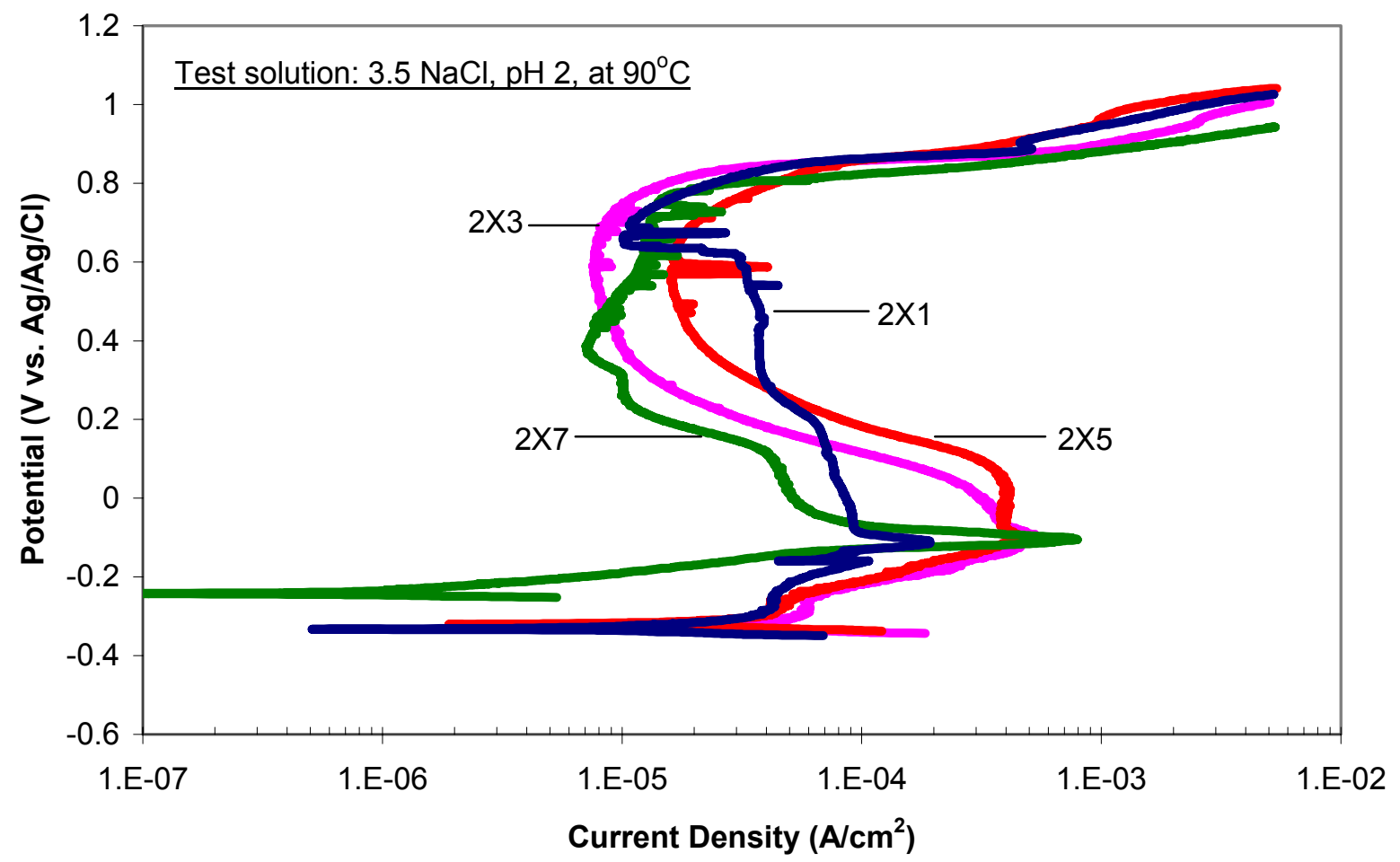

Figure 2. The corrosion resistance of SAM2X series ribbons in acidic ( $\mathrm{pH}$ 2) chloride solutions. SAM2X7 has the highest Mo content, while SAM2X1 has the lowest Mo content. 


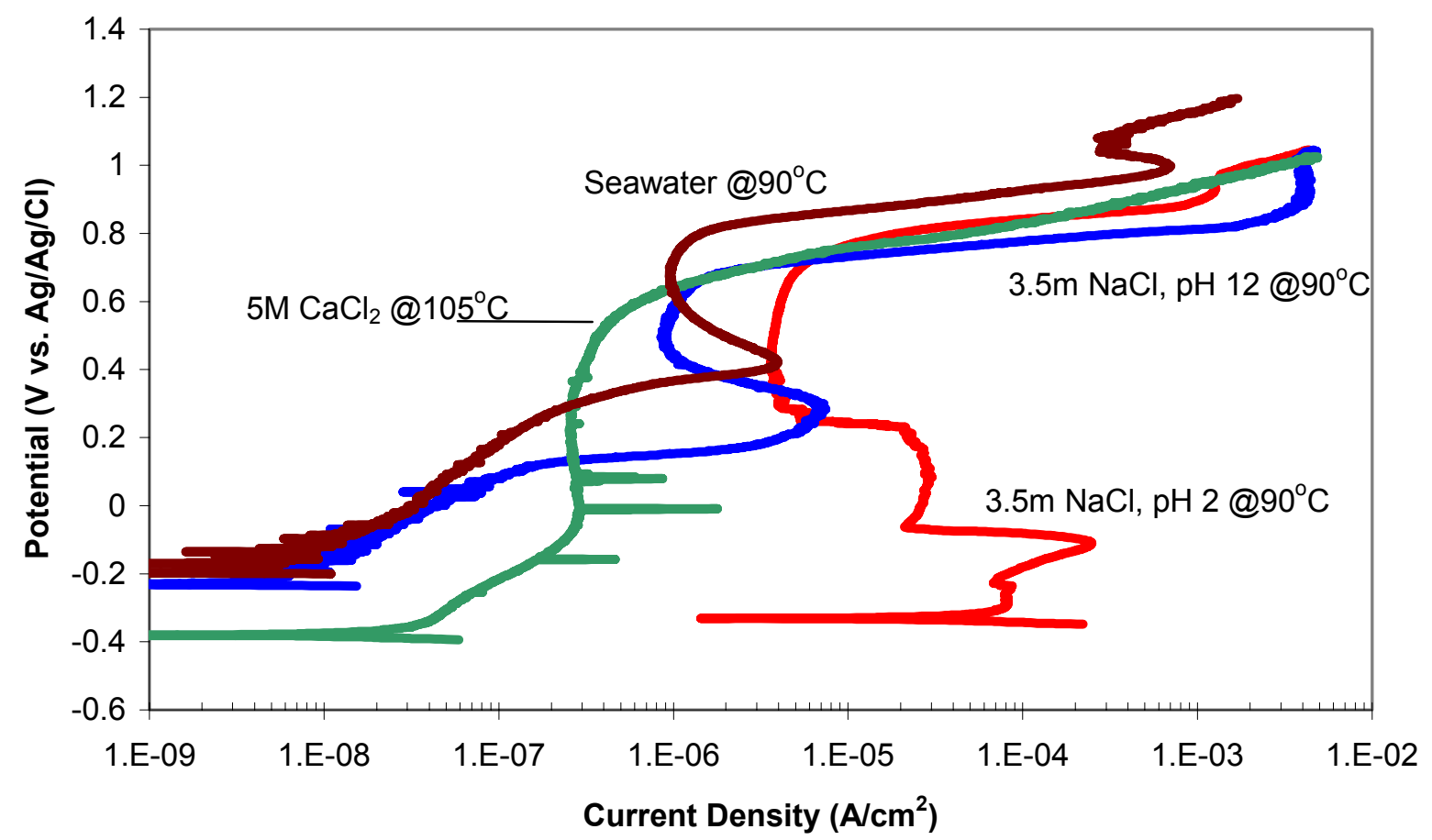

Figure 3. The corrosion resistance of DAR40 ribbon in various chloride solutions with $\mathrm{pH}$ ranging from 2 to 12. Both $5 \mathrm{M} \mathrm{CaCl}_{2}$ solution and seawater had a near neutral $\mathrm{pH}$.

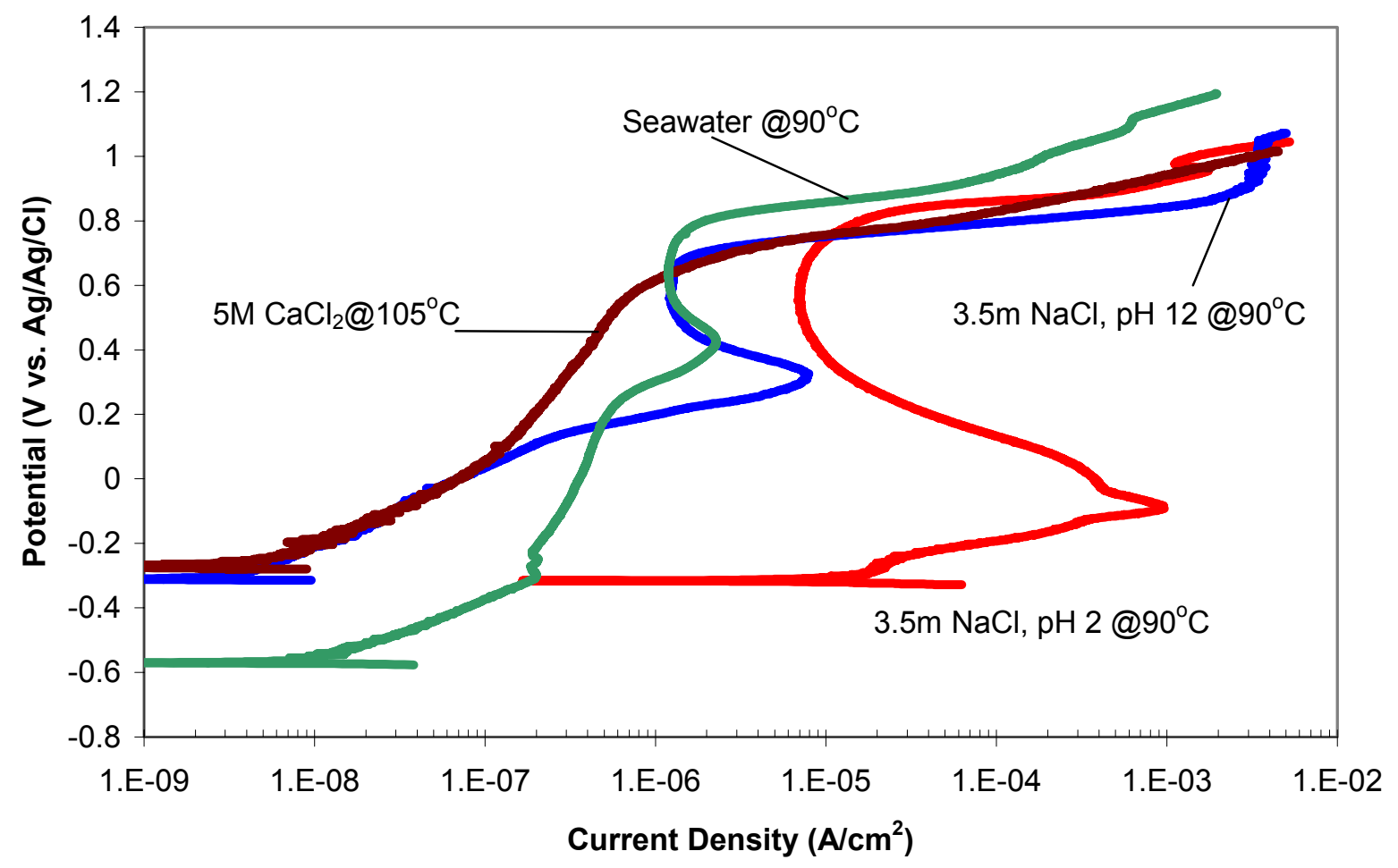

Figure 4. The corrosion resistance of SAM2X5 ribbons in various chloride solutions with $\mathrm{pH}$ ranging from 2 to 12 . Both $5 \mathrm{M} \mathrm{CaCl}_{2}$ solution and seawater had a near neutral $\mathrm{pH}$. 


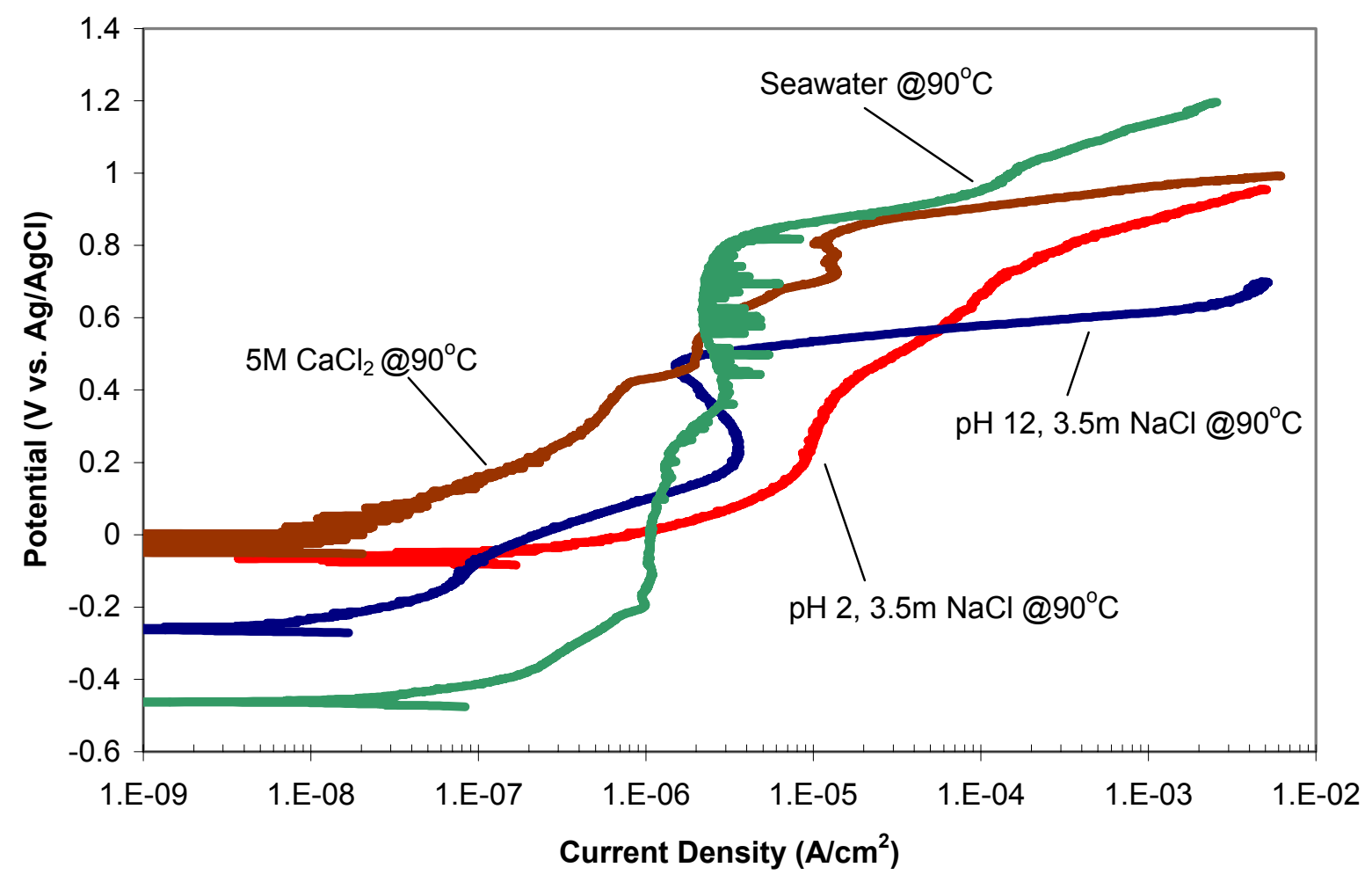

Figure 5. The corrosion resistance of SAM8 ribbons in various chloride solutions with $\mathrm{pH}$ ranging from 2 to 12. Both $5 \mathrm{M} \mathrm{CaCl}_{2}$ solution and seawater had a near neutral $\mathrm{pH}$. SAM8 is SAM7 with 3-atom $\% \mathrm{~W}$ added.

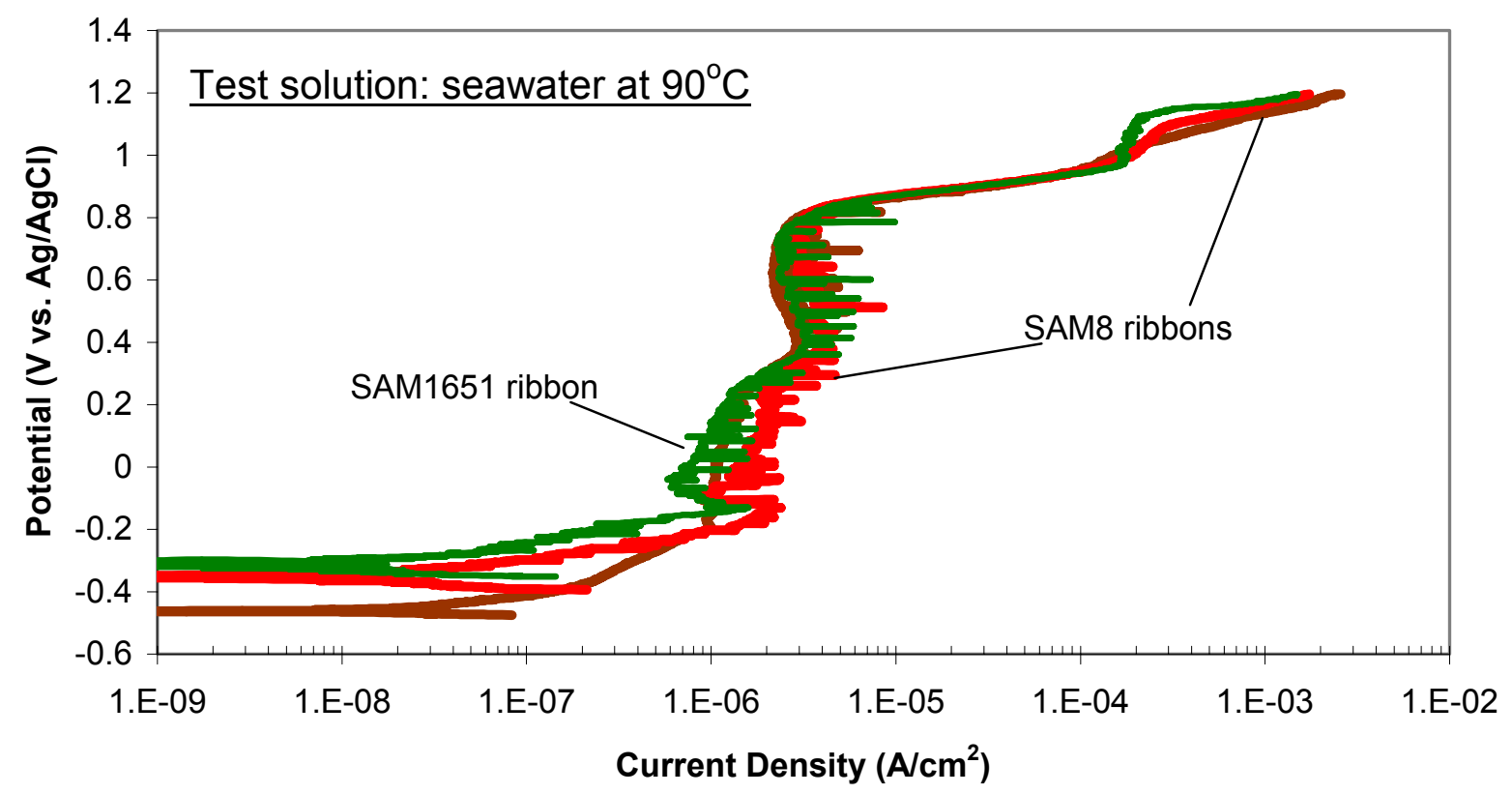

Figure 6. The corrosion resistance of SAM7 versus SAM8 ribbons in seawater at $90^{\circ} \mathrm{C}$. SAM8 is SAM7 with 3 -atom $\% \mathrm{~W}$ added. 


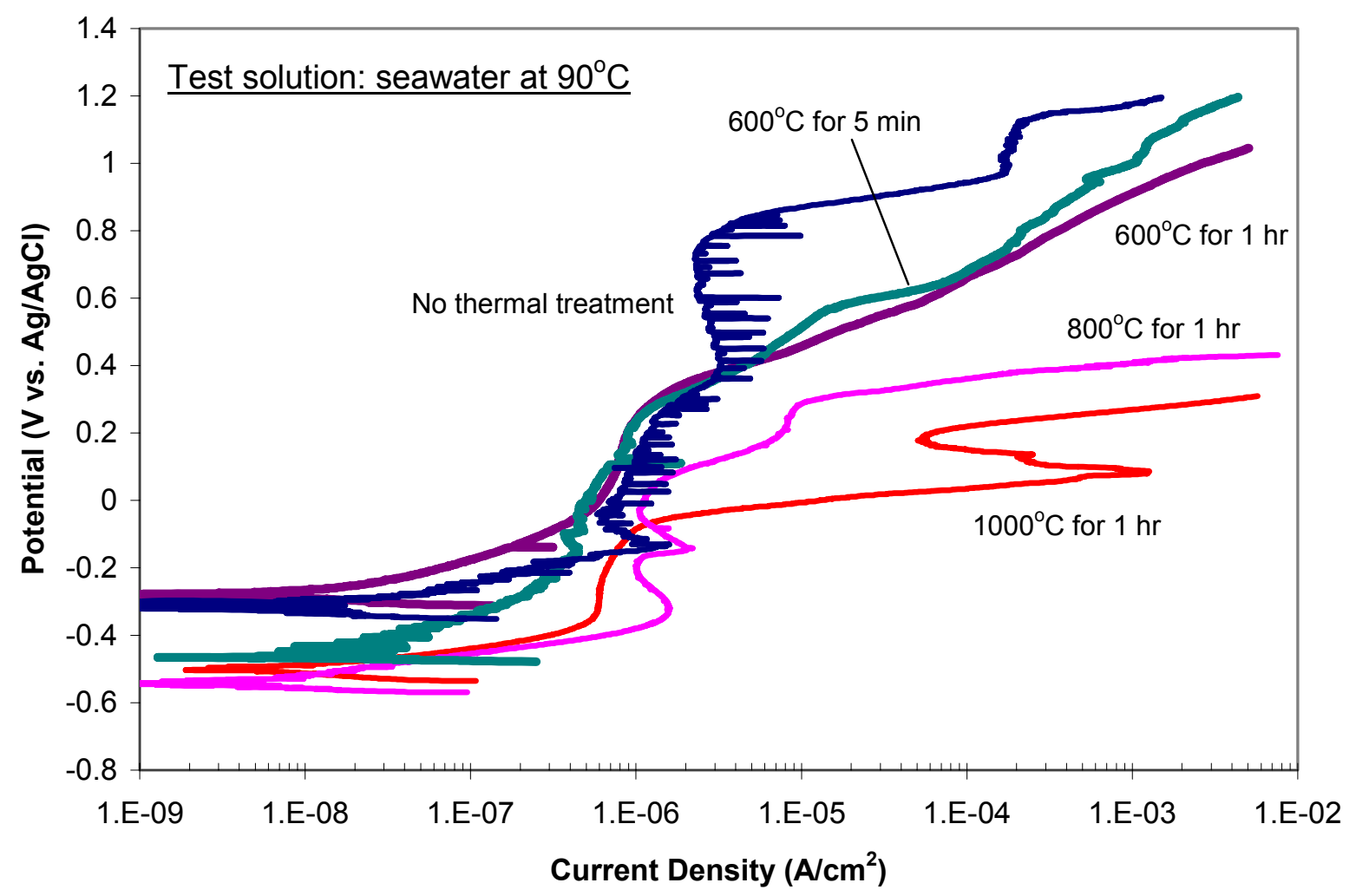

Figure 7. The effects of temperature on devitrification of SAM1651 ribbons have been illustrated by the changes in corrosion behavior. The devitrification temperature for SAM7 is reported around $680^{\circ} \mathrm{C}$. 